Герцберг Лора Яковлевна (Москва). Доктор технических наук, член-корреспондент РААСН. Главный научный сотрудник ФГБУ «Центральный научно-исследовательский и проектный институт Министерства строительства и жилищно-коммунального хозяйства» (119331 , Москва, просп. Вернадского, 29. ЦНИИП Минстроя России). Эл.почта: lgertz24@mail.ru.

Gertsberg Lora Yakovlevna (Moscow). Doctor of technical sciences, corresponding member of the RAACS. Chief researcher of the FGBU "The Central Institute for Research and Design of the Ministry of Construction and Housing and Communal Services of the Russian Federation" (119331, Moscow, Vernadskogo ave., 29. TsNIIP Minstroy of Russia). E-mail: Igertz24@mail.ru.

( Герцберг Л.Я., 2021. Academia. Архитектура и строительство, № 4, стр. 5-12.

\title{
Стратегия сбалансированного пространственного развития 2030: от научных обоснований к реализации
}

\author{
Л.Я.Герцберг, ЦНИИП Минстроя России, Москва
}

В статье рассматривается и предлагается обсудить ряд вопросов, связанных с реализаций Стратегии сбалансированного пространственного развития Российской Федерации 2030: политика искусственного увеличения численности населения агломераций и крупных городов, планируемое уплотнение агломераций за счёт размещения посёлков с типовой коттеджной застройкой для переселения населения из депрессивных поселений, создание единого института пространственного планирования. Эта политика разработана рабочей группой «Агрессивная инфраструктура», возглавляемой заместителем Председателя Правительства Российской Федерации М. Хуснуллиным. Рассмотрен первый этап реализации стратегических инициатив (2022-2024), Значительное внимание уделяется анализутрёх путей концентрации населения: переселение в агломерации 5 млн жителей из депрессивных малых поселений; стирание административных границ муниципальных образований, формирование агломераций на договорной основе. Отмечается, что несмотря на то, что во всём мире агломерации и крупные города рассматриваются как перспективные развивающиеся формы расселения, их количественный рост не всегда приводит к положительным качественным результатам. Эффективность агломераций повышается благодаря притоку специалистов высокой квалификации, стимулирующих развитие современных инновационных производств, а основу планируемого к переселению населения составляют пожилые, малообеспеченные возрастные группы с низкой квалификацией. Увеличение агломераций на договорной основе не всегда подкрепляется наличием тесных повседневных связей. Ресурсные обоснования планируемой стратегии недостаточны, они включают объём выделяемых средств, при этом потребные ресурсы не подсчитаны. Стратегия одобрена чиновниками, однако не получила необходимого обсуждения в научной среде. Это тем более актуально, что реализации стратегии начинается с 2022 года.

Ключевые слова: стратегия устойчивого и сбалансированного развития, искусственное формирование агломераций, депрессивные малые городские и сельские поселения, ресурсное обоснование
Sustainable Spatial Development Strategy 2030: from Scientific Evidence to Implementation

L.Ya.Gertsberg, TsNIIP Minstroy of Russia, Moscow

The article examines and proposes to discuss a number of issues related to the implementation of the balanced spatial development strategy of the Russian Federation 2030: the policy of artificial increase the population of agglomerations and large cities; the planned compaction of agglomerations through the placement of settlements with typical cottage buildings for the population from the depressed settlements and the creation of the Institute for Spatial Planning. The policy has been developed by the Aggressive Infrastructure Working Group, headed by Deputy Prime Minister of the Russian Federation Mr. Husnullin. Its implementation is envisaged at the first stage (2022-2024) of the strategic initiatives developed within the framework of the strategy for sustainable and balanced development of Russia 2030. There are 3 types of ways to concentrate the population: resettlement of 5 million inhabitants in the agglomerations from depressed small settlements; erasure of administrative boundaries; the formation of agglomerations on a contractual basis. It is noted that despite the fact that all over the world agglomerations and large cities are considered as promising forms of settlement, their quantitative growth does not always lead to the positive qualitative results. The efficiency of agglomerations grows as the results by the influx of highly qualified specialists who stimulate the development of the modern innovative industries. The resettled population base is made up of the elderly, low-income and low qualification's groups of the residents. Administrative changes in boundaries are not always supported by close daily ties. The resource justifications for the planned strategy are insufficient, include value of funds which are allocated without knowledge of the need. The strategy was approved by officials, but did not receive the necessary discussion in the scientific community. It is much more relevant because the implementation of the strategy begins in 2022.

Keywords: strategy of sustainable and balanced development, artificial formation of agglomerations, depressed small urban and rural settlements, resource justification. 


\section{Политика искусственного увеличения численности} населения агломераций и крупных городов

Распоряжением Правительства Российской Федерации от 13 февраля 2019 г. № 207-р. была утверждена Стратегия пространственного развития Российской Федерации на период до 2025 года. Основная цель пространственного развития определена как обеспечение устойчивого и сбалансированного пространственного развития Российской Федерации за счёт сокращения межрегиональных различий в уровне и качестве жизни населения, ускорения темпов экономического роста и технологического развития, а также обеспечение национальной безопасности страны. В марте 2021 года Минэкономразвития сообщило, что правительство РФ совместно с экспертами и бизнес-сообществом работает над новой стратегией социально-экономического развития, которая приняла форму стратегических инициатив. Распоряжением Правительства РФ от 6 октября 2021 года № 2816-р был утверждён перечень инициатив социально-экономического развития до 2030 года, в который вошли 42 инициативы по шести ключевым направлениям: социальная сфера, строительство, экология, цифровая трансформация, технологический рывок и государство для граждан [1]. По разным направлениям сформированы рабочие группы, в том числе группа «Агрессивное развитие инфраструктуры», которую возглавляет заместитель Председателя Правительства Российской Федерации Марат Хуснуллин. Задачей группы является разработка перечня инициатив, в том числе «Сбалансированного пространственного развития», в рамках которого планируются к реализации такие проекты, как «Возрождение малых форм расселения» и «Города больших возможностей» [2]. Основное внимание уделяется агломерациям как локомотивам экономического развития.

В Стратегии пространственного развития до 2025 года, как известно, было выделено двадцать агломераций для приоритетной государственной поддержки, что вызвало возражение у многих специалистов, считающих, что это приведёт к «опустыниванию» значительной части территории страны. Группой «Агрессивное развитие инфраструктуры» предусмотрена уже 41 крупная агломерация. Агломерации были выделены в зависимости от численности населения - более 500 тыс. человек, правда, с некоторой натяжкой, то есть с учётом городов, численность населения которых приближается к 500 тыс. человек. На Петербургском международном экономическом форуме (ПМЭФ2021) М. Хуснуллин отметил, что «развитие агломераций решит проблему отсталости регионов. Их будут развивать там, где есть университеты, а численность населения будет свыше 500 тысяч человек». По его прогнозам, к 2030 году в агломерациях будут жить 60 млн человек (почти половина населения России). В 15 агломерациях, как ожидается, темп роста экономики будет выше среднероссийского, а регионов-доноров станет в полтора раза больше. Однако в перечне стратегических инициатив, утверждённых Распоряжением Правительства РФ от 6 октября 2021 года № 2816-р, упоминается уже 105 агломераций, для которых вице-премьер обозначил приоритеты программы дорожного строительства («...довести до нормативного состояния 85\% дорог в 105 городских агломерациях, а также не менее 50\% региональных дорог и 85\% опорной сети») [3]. В настоящее время отношение к пороговым показателям численности населения агломераций изменилось. В стратегии пространственного развития, как известно, было выделено два типа агломераций, по критерию общей численности населения компактно расположенных населённых пунктов - от 500 тыс. до 1000 тыс. жителей и выше 1000 тыс. жителей. Однако в законопроекте об агломерациях количественный критерий отсутствует, и к агломерациям отнесены «городские округа, либо городские округа с внутригородским делением, либо города федерального значения, объединённые с территориями иных муниципальных образований устойчивыми социальными, экономическими и хозяйственными связями».

Согласно информации Минэкономразвития, в рамках этой инициативы предлагается создать условия для интенсивного экономического развития 41-ой крупной агломерации, а также для опорных населённых пунктов сельских территорий». В рамках этой инициативы, предполагается «ввести единую градостроительную и транспортную политику в городских агломерациях, синхронизировать государственное финансирование мероприятий на сельских территориях, развивать инфраструктуру, а также прорабатывать нормативную базу для опережающего развития городских агломераций» [4].

В российских регионах также предполагается создать межгородские агломерации, проект коснётся 37-ми субъектов страны. Однако эксперты считают, что агломерации могут создать проблемы с властями на местах. Полный список агломераций (в том числе четыре межрегиональные) будет прописан в поправках к закону «0б общих принципах организации местного самоуправления», которые разрабатывает Минфин России. В законе будут содержаться условия для создания межгородских агломераций и стимулирования регионов и муниципалитетов к заключению соглашений о сотрудничестве и совместном развитии инфраструктур [5].

Цель государственной поддержки агломераций - повышение качества среды проживания и эффективное развитие экономики. Председатель Правительства РФ М. Мишустин отметил, что «все эти инициативы нужны для более эффективного достижения национальных целей, которые были определены главой государства на ближайшие десять лет, а также решения задач, которые глава государства поставил в посланиях Федеральному Собранию». Он также сообщил, что ход реализации стратегических инициатив будет детально обсуждён на Российском инвестиционном форуме в Сочи, который запланирован на 17-19 февраля 2022 года. Планируется, что к 2030 году в агломерациях должно вдвое вырасти качество городской среды (оно определяется по таким критериям, как безопасность, комфорт, экологичность, разнообразие, современность, эффективность управления). М. Хуснуллин отметил, что «задача - сделать единую среду качества жизни независимо от административных границ». В более, чем сорока агломерациях с населением более 60 млн человек будут созданы условия для ускоренного эконо- 
мического развития. А более 15-ти агломераций с населением более 35 млн человек будут иметь темпы экономического роста выше среднероссийского [4].

Предусмотрено два этапа формирования агломераций - 2024 год и 2030 год. На начальном этапе рассматривается вариант «искусственного роста численности населения агломераций» и формирования городов-миллионников. Искусственный рост будет достигаться следующими путями: переселением в агломерации 5 млн жителей из неперспективных малых городов и посёлков; стиранием межмуниципальных границ, заключением межмуниципальных договоров [4].

Генеральный директор фонда «Институт экономики города» А. Пузанов отмечает, что «для массового переселения людей планируется строительство новых микрорайонов на месте ветхого жилого фонда в центрах агломераций, на свободных территориях, на территориях между населёнными пунктами агломераций» [6]. Создание коттеджных посёлков для переселения жителей поддерживается планами развития индивидуального жилищного строительства и комплексного развития территорий (КРТ) в рамках направления «Возрождение малых форм расселения». Предполагается, что переселенцы из аварийных домов получат новое жильё бесплатно, другие категории населения смогут купить квартиры или построить индивидуальный дом (ИЖС) [5]. Несмотря на то, что намечается строительство дешёвого типового жилья, размещение его на дорогих землях агломерации с комплексным инженерным обустройством приведёт к значительному повышению стоимости.

Возникает опасение, что путь планируемого роста численности населения агломераций и решения проблем повышения качества жизни путём переселения населения может быть не поддержан населением. Это объясняется целым рядом причин, прежде всего, демографическим и социальным составом населения, проживающего на территории депрессивных малых поселений. Разрушенная социальная инфраструктура, отсутствие мест приложения труда привели к оттоку молодёжи и квалифицированных специалистов, в малых депрессивных поселениях остались пожилые люди с мизерными доходами, выживающие за счёт приусадебных участков. Известный специалист в области региональной экономики Н Зубаревич отмечает, что «депопулирующие малые города и посёлки периферийной России с постаревшим населением рассредоточены по всей стране, их особенно много в Центральной России, на Северо-Западе, в промышленных регионах Урала и Сибири, в Южном и Северо-Кавказском федеральных округах (27 проц. всех сельских жителей страны)... Например, в Псковской области более 40 проц. всех сельских жительниц - пенсионерки, большинство сельскохозяйственных предприятий убыточны, а неаграрный бизнес развивается в сельской местности очень медленно. Дееспособное население периферий с низким аграрным потенциалом фактически вернулось к собирательству и зарабатывает на жизнь сбором грибов, ягод, кедровых шишек, ловлей рыбы. На Сахалине есть небольшие сёла, в которых, за исключением бюджетной сферы, вообще нет других рабочих мест, но люди не уезжают: сезон путины, когда красная рыба идёт на нерест, обеспечивает теневыми заработками на весь год. Занятость в теневой экономике позволяет не зависеть от государства» [7]. С аналогичной ситуацией мы столкнулись при разработке генерального плана г.о Комсомольск-на-Амуре, когда население не захотело переезжать с затопляемых территорий после наводнения по тем же причинам. Таким образом, с одной стороны, у планируемого к переселению населения нет денег на покупку и аренду нового жилья, с другой стороны, оно теряет добавку к мизерной пенсии за счёт доходов от земли и льготы, предоставляемые в сельской местности. Поэтому в том случае, если переселение будет производиться насильственно, это может привести к социальным конфликтам. В силу указанных причин реализация в полной мере данного сценария представляется малореальной, но даже, если предположить, что его удастся осуществить, то что в социальном плане будут представлять коттеджные посёлки, где сконцентрировано население из депрессивных малых поселений. Ведь политика устойчивого развития исключает социальную сегрегацию населения.

Следует отметить, что политика переселения населения из неперспективных сел не нова. В 1960-1970 годы благодаря «политике неперспективных сёл», были уничтожены тысячи населённых пунктов. В последствии её называли одной из причин системного кризиса, «катастрофы» села [8].

Планируемая политика обезлюживания малых поселений не должна ориентироваться только на их существующее депрессивное состояние без оценки ресурсов развития. В контексте политики переселения особого внимания требуют вопросы сохранения и развития сельскохозяйственного производства как залога решения проблемы продовольственной безопасности страны, учёта факторов геополитического положения и безопасности страны. сохранения исторических поселений, использования богатого туристического рекреационного потенциала. С 2002 года, согласно приложению к «Федеральной целевой программе “Сохранение и развитие архитектуры исторических городов (2002-2010 годы)"», в Российской Федерации насчитывалось 478 населённых пунктов, имеющих статус исторических поселений федерального значения. В 2010 году в списке исторических поселений федерального значения Министерство культуры РФ оставило только 41 населённый пункт. Ряд населённых пунктов, не получивших федерального статуса, впоследствии приобрели статус исторического поселения регионального значения. Переоценка количества исторических населённых пунктов федерального значения связана не со снижением ценности наследия, a, скорее, с сокращением финансовых возможностей государственной поддержки. Депрессивные поселения, исключённые из списка исторических, могут иметь ресурсы для перспективного развития. А. Швецов отмечает, что характерными именно для зрелых европейских агломераций стали процессы разгрузки агломераций и реновации депрессивныхтерриторий [9]. Большую роль в реновации играет развитие творческих индустрий. Россия обладает богатым историко-культурным потенциалом, который обеспечивает возможность для развития творческих индустрий. 
В рамках направления «Города больших возможностей» Минэкономразвития России планирует создать систему поддержки «креативного сектора» (к нему относят архитектуру, дизайн, моду, изобразительное и исполнительское искусство, музыку, кино и анимацию, видеоигры, телерадиовещание, рекламу и т.д.): «творческие инкубаторы», «точки концентрации талантов», «инклюзивные творческие лаборатории». На поддержку креативного сектора намечают выделить 45 млрд руб. К 2030 году ставится цель довести экспорт продукции креативных индустрий до \$24 млрд (по сравнению с менее \$4 млрд сейчас). К этому же времени креативные индустрии должны будут приносить в бюджетную систему страны 534 млрд руб. в виде налогов и страховых взносов (сейчас - 34 млрд руб.) [10]. К креативным индустриям также относятся народные ремёсла и народное творчество, которые могут быть возрождены на территориях некоторых депрессивных малых поселений. В монографии «Кластеризация экономики и расселение населения» рассмотрены проблемы депрессивных территорий, которые можно решать путём развития творческий индустрий [11]. Поэтому принятию решений о судьбе депрессивных поселений должно предшествовать исследование наличия возможных источников их возрождения. На это целесообразно направить часть средств, выделяемых на развитие творческих индустрий.

Не новым является также принцип «стирания границ». Процесс наделения городов статусом городских округов (определён Федеральным законом от 6 октября 2003 года № 131-Ф3 «0б общих принципах организации местного самоуправления в Российской Федерации»), сопровождался включением в городскую черту образуемых округов ближайших муниципальных образований.

Иллюстрацией современного подхода к стиранию границ муниципальных образований «административным» способом может служить намерение сделать Владивосток миллионником. Сейчас в нем проживает 600,9 тыс. жителей, к нему присоединят расположенный в 38 км город Артём - 104,9 тыс. жителей. В этом городе находится находится аэропорт и новый микрорайон - Надеждинское, на базе которого намечается создать новый город-спутник и привлечь в него ещё 300 тыс. жителей. При этом следует отметить, что численность населения как Владивостока, так и Артёма в последние годы не растёт и даже немного сокращается. Причём, незначительное сокращение численности населения поддерживается за счёт изменения этнического состава населения, увеличения притока в город китайцев, таджиков, узбеков, киргизов и сокращения традиционно проживающих украинцев, белорусов, русских, татар. Фактически квалифицированные кадры убывают, население пополняется за счёт менее образованных иммигрантов. Каковы интересы города Артёма при присоединении к Владивостоку? Артём - самодостаточный город, когда-то здесь добывался уголь, но после закрытия шахты появилось много новых производств, был создан транспортнологистический комплекс. На сельских территориях городского округа развиваются фермерские хозяйства. Что произойдёт с фермерскими хозяйствами в случае «стирания границ» и при- соединения всей территории к Владивостоку? Глава Минвостокразвития России Алексей Чекунков заявил, что Владивосток должен стать третьим по привлекательности городом России по всем параметрам после Москвы и Санкт-Петербурга с населением 1 млн человк и сейчас прорабатывается бизнес-проект создания города-спутника [12].

Ещё одна современная модель образования новых и развития существующих агломераций - договорная. Об этом пишет А. Боков: «Границы агломераций носят договорной характер, их можно назначить исходя из часовых или полуторачасовых изохрон, можно сделать это, опираясь на границы муниципалитетов, вступивших в соглашение о совместном развитии» [13]. Эта модель позволяет наиболее быстро увеличивать численность населения агломераций путём роста договоров, заключённых с муниципальными образованиями. Пример - Барнаульская агломерация, которая сначала включала близлежащие к городу, наиболее тесно связанные муниципальные образования: городской округ Барнаул, городской округ Новоалтайск, Первомайский район, затем был присоединён Павловский район, и общая численность населения на 2021 год составила 862968 человек. В ядре агломерации Барнаул, Новоалтайск, сконцентрировано 770126 человек. Затем было подписано соглашение о взаимодействии Ассоциации «Барнаульская агломерация» с Калманским и Тальменским районами. Соглашение - это первый шаг к вступлению этих районов в состав агломерации. Такое стремление к объединению связано с желанием региональной власти создать крупную агломерацию, которая получит первоочередную государственную поддержку.

Чем можно объяснить на первом этапе реализации стратегических инициатив (2002-2004 годы) государственную политику искусственного увеличения численности населения агломераций? Прежде всего, намерением ускорить решение важнейшей социальной задачи - повышение качества жизни населения путём приближения его к благам, которые даёт агломерация: развитая социальная сфера, выбор образовательных услуг, мест приложения труда, большая, но все равно недостаточно высокооплачиваемая работа и др. Глава Центробанка Эльвира Набиуллина во время выступления в Госдуме заявила, что «обеспечение существенных сдвигов в качестве жизни без изменения сложившейся модели социально-экономического развития невозможно. Никий уровень оплаты труда при сложившейся структуре российской экономики становится главным тормозом экономического роста и качественных сдвигов в социальной сфере» [14].

Другая задача, которую пытаются решать с помощью политики искусственного роста агломераций - развитие экономики. Агломерации рассматриваются как локомотивы экономического роста и развития современной инновационной экономики. Это подтверждается отечественными и зарубежными специалистами. В ходе подготовки «Стратегии пространственного развития Российской Федерации» Центр экономики инфраструктуры провёл оценку вклада крупнейших городских агломераций в ВВП и в экономический рост, который показал, что на 9 крупнейших 
агломераций с населением свыше 1,5 млн человек приходится менее 30\% населения России, но свыше 40\% ВВП и почти 40\% всего прироста ВВП за 2010-2016 годы. Агломерации на 80-90\% состоят из услуг. И для них эффект близости - ключевой фактор. Благодаря эффекту масштаба одни и те же предприятия, которые находятся в зоне влияния агломераций, как правило, в 1,5-2 раза более производительны, чем предприятия, находящиеся в небольших населенных пунктах, вдали от крупных городских центров [15]. Ставка на развитие агломераций соответствует мировым трендам. Сегодня на триста крупнейших агломераций приходится около $47 \%$ мирового ВВП и $20 \%$ населения Земли [15]. Довольно распространено мнение, что развитие городских агломераций тянет за собой развитие прилегающих территорий. Но на примере наших крупнейших агломераций - Московской и Санкт-Петербургской мы наблюдаем совершенно другую картину. Они как пылесосы вытягивают квалифицированные кадры из территорий прилегающих субъектов РФ.

Возникает вопрос «всегда ли количественный рост агломераций даёт качественный эффект»? При искусственном росте величины агломераций в сферу их влияния вовлекаются малоквалифированные группы населения, которые вряд ли существенно повысят производительность труда. В условиях глобализации экономическая конкурентоспособность стран определяется конкуренцией крупнейших агломераций, которая обеспечивается за счёт привлечения специалистов высокой квалификации, проживающих как внутри страны, так и за её пределами путём создания качественной среды проживания, развития современных инновационных производств, адекватной оплаты труда. Тезис о том, что «количественный рост агломераций не всегда перерастает в качество, подтвердили социологические исследования Департамента социологии Финансового университета при правительстве РФ в 2014 году. Исследования крупных городов, формирующих агломерации, выявили топ 10 бедных городов (Тольятти, Астрахань, Пенза, Волгоград, Саратов, Липецк, Барнаул, Ростов-на-Дону, Воронеж, Набережные Челны), куда, как видно, попали также города-миллионники. Это связано с недостатком количества рабочих мест, невозможностью восстановить обанкротившиеся предприятия, создать новые места приложения труда, низкой социальной поддержкой граждан. В результате пандемий за прошедший период эта ситуация только усугубилась [16].

В развитых странах агломерации также растут за счёт мигрантов, большая часть которых имеет низкую квалификацию, но качественный рост достигается за счёт специалистов, которые приезжают со всего мира. И развитие агломераций начинается с формирования современной инфраструктуры, заключения договоров с инвесторами на развитие вдоль магистралей инновационных производств, которые обрастают жилыми образованиями с развитой социальной инфраструктурой, своими многофункциональными центрами, позволяющими снизить центростремительные потоки населения в города-ядра.

Политика искусственного увеличения численности населения агломераций поддержана чиновниками, но необходимого обсуждения в научной среде не получили следующие её аспекты:
- целесообразно ли в условиях ограниченных финансовых и квалифицированных трудовых ресурсов распыление средств между 41-ой и 105-ью агломерациями за короткий период времени. Не лучше ли вернуться к предложению Э. Набиуллиной выбрать 15-20 агломераций для приоритетного решения вопросов повышения качества среды проживания и осуществления экономического прорыва. Приоритетная поддержка не означает лишения других территорий помощи;

- являются ли приоритетными задачи количественного роста численности населения агломераций и крупных городов или задачи повышения качества среды проживания, в том числе за счёт полицентричного развития агломераций;

- относится ли к числу первоочередных задача формирования опорных центров расселения в сельской местности, реабилитация депрессивных территорий;

- можно ли ожидать получения социального и экономического эффекта от искусственной концентрации населения в агломерациях и крупных городах.

\section{Планируемое уплотнение агломераций за счёт размещения типовой коттеджной застройки}

Отрицательной стороной политики искусственного развития агломераций является планируемое вторжение в агломерации посёлков коттеджной застройки в отсутствие стратегических планов развития агломераций. При этом не исключена застройка сельскохозяйственных земель, вырубка лесных массивов - то, что мы наблюдаем в Московской области при строительстве микрорайонов-«муравейников» с высокой плотностью застройки. Процесс джентрификации депрессивных промышленных территорий, сопровождаемый строительством нового жилья, преимущественно коммерческого, приводит к дальнейшей концентрации населения в ядрах агломераций и росту центростремительных тенденций. В качестве примера можно привести застройку в Москве промзоны Тушинского завода железобетонных изделий, где планируется возвести 450000 кв. м недвижимости, из которых 352000 кв. м - коммерческий жилой комплекс. Чуть менее 2 га будет передано под программу реновации, под эти цели построят 82000 кв. м. Остальное составят объекты инфраструктуры. Только за счёт этой территории население может прирасти на 20000 жителей [17].

Руководитель Института региональных проблем Дмитрий Журавлев, ссылаясь на зарубежный опыт, поддерживает строительство коттеджных посёлков и постоянные поездки их обитателей в центр агломерации: «Схема очень похожа на американскую: люди живут в небольших пригородах, а на работу, на учёбу ездят в центральный город» [4]. К слову сказать, такой опыт есть и в отечественной практике. Разница между существующей и планируемой ситуацией в том, что сейчас в коттеджных посёлках, расположенных в комфортной близости от ядер агломераций, проживают наиболее обеспеченные группы населения, предпочитающие квартире отдельный дом в хорошем природном окружении с более благоприятной экологией, при этом часть этого населения имеет второе жильё в городе. Можно 
предположить, что массовое строительство дешёвых коттеджных посёлков с плотной типовой застройкой приведёт к нарушению рыночного принципа - «дорогие земли должны застраиваться дорогой недвижимостью».

Такая концепция заселения агломераций наряду с формированием опорных центров расселения трактуется как возрождение малых форм расселения. Ей соответствуют планы правительства по поддержке индивидуального жилищного строительства и комплексному развитию территорий (КРТ). Несмотря на то, что федеральные органы власти ещё только прорабатывают эти вопросы в регионах, процесс уже пошёл: Пермский край, Тюменская область уже получили инфраструктурный кредит на строительство новых микрорайонов. Регионы активно планируют создание новых агломераций и опорных населённых пунктов, в Удмуртии вокруг столицы республики Ижевска - создаётся агломерация Ижевск-Сарапул-Воткинск. «Но на севере республики есть ещё город Глазов (100-тысячник, и вокруг - тяготеющие к нему сельские населённые пункты), который планируется как опорный пункт для системы расселения [4]. Планируется создание Сахалинской агломерации. Согласно прогнозу Минстроя за период с 2022 по 2024 годы предполагается ввести 175,6 млн кв м., из которых, по расчётам, не менее $60 \%$ должно пойти на строительство жилого фонда для переселения населения [18].

Переселение населения из неперспективных городских и сельских поселений в агломерации и крупные города может иметь не только социальные, экономические, но и градостроительные последствия, которые также должны быть предметом обсуждения в научной среде:

- можно ли размещать посёлки с типовой коттеджной застройкой при отсутствии документов стратегического пространственного планирования агломераций, ориентируясь только на территории размещения аварийного фонда или джентрификацию промышленных зон;

- реальна ли покупка или аренда коттеджей малоимущими слоями населения или в, конечном счёте, коттеджи будут приобретаться другими группами населения, переезжающими из более перспективных городов, что усилит нагрузку на транспортную сеть и центростремительные тенденции;

- приведёт ли такая политика к занятию ценных земель агломераций, расположенных в 30-километровой от ядра агломерации зоне, типовой коттеджной застройкой, вырубке лесов, застройке сельскохозяйственных земель;

- вызовет ли социальную напряжённость формирование посёлков, где будут сконцентрированы пожилые малообеспеченные группы населения.

\section{Создание единого института пространственного планирования}

Минэкономразвития заявил о создании Единого института пространственного планирования с целью формирования условий для сбалансированного пространственного развития. Вопросы пространственной организации расселения и про- ектирования развития городов остаются разделёнными между двумя ведомствами. За два направления пространственной организации систем расселения «Города больших возможностей и возрождение малых форм расселения» и «Реинжиниринг правил промышленного строительства» - будет отвечать Минэкономразвития России, а Минстрой России будет вести четыре проекта: «Мобильный город», «Мой частный дом», «Инфраструктурное меню», «Новый ритм строительства». Кроме того, Росреестру поручено курировать инициативу «Национальная система пространственных данных».

Проект «Мой частный дом» предусматривает развитие индивидуального жилищного строительства (ИЖС) через внедрение институтов типового проектирования, серийного производства и ипотечного кредитования для данного сегмента жилья [3]. Видимо, вопросами типового проектирования будет заниматься Институт пространственного планирования, который предположительно намечается создать на базе ФГБУ «ЦНИИП Минстроя», хотя, целесообразно было бы возродить и укрепить квалифицированными кадрами необходимого профиля существовавший на его месте «Центральный научно-исследовательский и проектный институт градостроительства», который, наряду с формированием научно-методической базы, занимался разработкой районных планировок, генеральной схемы расселения, схем территориального планирования, генеральных планов городов, и закрепить за ним функции пространственной организации систем расселения, что больше бы соответствовало и новому названию института. Ведь стратегическое планирование с его основной задачей - обеспечение устойчивого сбалансированного развития - требуют комплексного междисциплинарного подхода. В крайнем случае, институт может иметь двойное подчинение. Институт пространственного планирования создаётся на базе научно-исследовательского и проектного института, с учётом этого должна определяться его деятельность, которая должна включать:

- методические вопросы разработки документов стратегического пространственного планирования;

- разработку нормативной базы;

- экспериментальное проектирование;

- экспертизу документов стратегического планирования;

- участие в разработке законодательной базы в области стратегического пространственного планирования;

- формирование информационной базы в области стратегического планирования;

- обобщение и анализ прогрессивного зарубежного опыта. $* * *$

Представляется целесообразным обсудить затронутые в статье вопросы, тем более, что наступает год начала реализации стратегических инициатив ещё не наступил.

\section{Литератураы}

1. Минэкономразвития дорабатывает стратегию социально-экономического развития [Электронный ресурс] // TACC. Официальный сайт. - Режим доступа: https://tass.ru/ 
ekonomika/11597723 (дата общения 09.12.2021).

2. Мальщев В. Власти решили согнать $85 \%$ россиян в агломерации, а деревню отдать гастарбайтерам [Электронный ресурс] / В. Мальцев // ЗАВТРА. - Режим доступа: https://zavtra.ru/blogs/ vlasti_reshili_sognat_85_rossiyan_v_aglomeratcii_a_derevnyu_ otdat_gastarbajteram (дата обращния 07.12.2021).

3. 85\% дорог и 105 городских агломераций приведут до нормативного состояния до 2024 года [Электронный ресурс] // Стратегия 24 - общероссийская цифровая платформа. - Режим доступа: https://strategy24.ru/rf/news/85-dorog-v105-gorodskikh-aglomeratsiyakh-privedut-do-normativnogosostoyaniya-do-2024-goda (дата обращения 08.12.2021).

4. Трубилина М. Минэкономразвития займется агломерациями и опорными населенными пунктами [Электронный ресурс] / М. Трубилина // Российская газета. Официальный сайт. Режим доступа: https://rg.ru/2021/10/12/minekonomrazvitiiazajmetsia-aglomeraciiami-i-opornymi-punktami-na-sele.html (дата обращения 25.11.2021)

5. В 37 регионах России будут объединять города. Комментарий А.С. Пузанова [Электронный ресурс] // Официальный сайт фонда «Институт экономики города». Режим доступа: https:// urbaneconomics.ru/centr-obshchestvennyh-svyazey/news/v-37regionah-rossii-budut-obedinyat-goroda-kommentariy-puzanova (дата обращения 11.12.2021,

6. Правительство РФ расселит миллионы россиян по агломерациям. Комментарий А.С. Пузанова [Электронный ресурс] // Официальный сайт фонда «Институт экономики города». Режим доступа: https://urbaneconomics.ru/en/node/21501 (дата обращения 11.12.2021).

7. Зубаревич, Н. Социальная дифференциация регионов и городов [Электронный ресурс] / Зубаревич // PRO ET CONTRA. 2012. - Том. 16. - № 4-5. - С. 135-152. - Режим доступа: https:// elibrary.ru/item.asp?id=25653327 (дата обращения 01.12.2021). Русс. Англ.

8. Мазур, Л.Р. Политика ликвидации неперспективных деревень в 1960-1970-е гг.:истоки, этапы, реализация,результать (на материалах Урала) [Электронный ресурс] / Л.Н. Мазур // Россия в XX в.: история и историография : Сборник научных статей. - Режим доступа: https://elar.urfu.ru/bitstre am/10995/54585/1/5-7996-0150-5_2002_08.pdf (дата обращения 25.11.2021) русс.

9. Швецов, А.Н. Поляризация урбанистического пространства: особенности российского процесса в контексте мировых тенденций [Электронный ресурс] / А.Н. Швецов // Регионалистика. - 2017. - Том 4. - № 5. - С. 20-34. - Режим доступа: https://elibrary.ru/item.asp?id=30506831 (дата бращения 16.11.2021).

10. Дмитриев М. Экономическая гравитация. Центростремительные и центробежные силы агломерации [Электронный ресурс] / М.Дмитриев // Больше, чем город. Границы, масштаб и гравитация городских агломераций : Сборник статей к Московскому урбанистическому форуму. -M. : MUF, 2021. - C. 28-43. - Режим доступа: https://vk.com/doc130708286_588149279?h $\mathrm{ash}=5 \mathrm{eb} 13 \mathrm{f} 472 \mathrm{be} 40214 \mathrm{bc}$ (дата обращения 12.12.2021).

11. Герцберг Л.Я. Кластеризация экономики и расселение населения : Монография / Л.Я. Герцберг. - М. : Новая реальность, 2021. - 180 c.

12. «На Дальнем Востоке собираются создать первый город-миллионник» - из интервью с министром по развитию Дальнего Востока и Арктики С.Чекункова [Электронный ресурс] // REGNUM/ - Режим доступа: https://regnum.ru/news/3357420. html (дата обращения 06.12.20212).

13. Боков, А.В. Агломерации: мнимое и реальное [Электронный ресурс] / А.В. Боков // «Строительный Эксперт». Портал для специалистов архитектурно-строительной отрасли. - Режим доступа: https://ardexpert.ru/article/16422 (дата обращения 06.12.2021),

14. Ахтырко, А. Инфляция стала двузначной, кредиты ограничат. 0 чем рассказали в ЦБ. Набиуллина: продовольственная инфляция достигла двузначных значений [Электронный ресурс] / А. Ахтырко // ГАЗЕTA.RU. - Режим доступа: https://www. gazeta.ru/business/2021/11/18/14218081.shtml (дата обращения 10.12.2021).

15. Bouchet, M. Global Metro Monitor 2018 / Max Bouchet, Sifan Liu, Joseph Parilla, Nader Kabbani. - Brookings Institution, June 2018.

16. Диков, Я.А. Тенденции развития городских агломераций [Электронный ресурс] / А.Я. Диков // Экономика и бизнес: теория и практика. - 2017. - № 7. - С. 24-28. Русс. Англ. -

17. На месте завода в Тушине появится жилой квартал на 500 000 кв. м [Электронный ресурс] // Ведомости. - Режим доступа: https://www.vedomosti.ru/realty/articles/2020/09/08/839089zavoda-tushine (Дата обращени06.12.2021).

18. Минстрой сохраняет прогноз по вводу 85,6 млн кв.м жилья [Электронный ресурс] // Интерфакс-Недвижимость. - Режим доступа: https://realty.interfax.ru/ru/news/articles/129195/ (дата обращения 10.12.2021).

\section{References}

1. Minekonomrazvitiya dorabatyvaet strategiyu sotsial'noekonomicheskogo razvitiya [The Ministry of Economic Development is finalizing the strategy of socio-economic development]. TASS. Ofitsial'nyi sait [TASS. Official site]. - Access mode: https://tass.ru/ ekonomika/11597723 (data obshcheniya 12/09/2021). (In Russ.)

2. Mal'tsev V. Vlasti reshili sognat' $85 \%$ rossiyan vaglomeratsii, a derevnyu otdat' gastarbaiteram [The authorities decided to drive $85 \%$ of Russians in the agglomeration, and give the village to guest workers]. ZAVTRA. Access mode: https://zavtra.ru/blogs/ vlasti_reshili_sognat_85_rossiyan_v_aglomeratcii_a_derevnyu_ otdat_gastarbajteram (Accessed 12/07/2021). (In Russ.)

3. $85 \%$ dorog i 105 gorodskikh aglomeratsii privedut do normativnogo sostoyaniya do 2024 goda [ $85 \%$ of roads and 105 urban agglomerations will bring them to the norm by 2024]. In: Strategiya 24-obshcherossiiskaya tsifrovaya platform [Strategy 24 the all-Russian digital platform]. Access mode: https://strategy24. ru/rf/news/85-dorog-v-105-gorodskikh-aglomeratsiyakhprivedut-do-normativnogo-sostoyaniya-do-2024-goda (Accessed 
12/08/2021). (In Russ.)

4. Trubilina M. Minekonomrazvitiya zaimetsya aglomeratsiyami i opornymi naselennymi punktami [The Ministry of Economic Development will deal with agglomerations and basic settlements]. In: Rossiiskaya gazeta. Ofitsial'nyi sait [Rossiyskaya Gazeta. Official site]. Access mode: https://rg.ru/2021/10/12/minekonomrazvitiiazajmetsia-aglomeraciiami-i-opornymi-punktami-na-sele.html (Accessed 211/25/2021)/ (In Russ.)

5. V 37 regionakh Rossii budut ob"edinyat' goroda. Kommentarii A.S. Puzanova [Cities will be united in 37 regions of Russia. Comments of A.S. Puzanov]. In: Ofitsial'nyi sait fonda «Institut ekonomiki goroda» [Official site of the Institute for Urban Economics Foundation]. Access mode: https://urbaneconomics.ru/centrobshchestvenyazey/news/v-37-regionah-rossii-budut-obedinyatgoroda-kommentariy-puzanova (Accessed 12/11/2021)/ (In Russ.)

6. Pravitel'stvo RF rasselit milliony rossiyan po aglomeratsiyam. Kommentarii A.S. Puzanova [he Government of the Russian Federation will resettle millions of Russians in agglomerations. Comments of A.S. Puzanov]. In: Ofitsial'nyi sait fonda «Institut ekonomiki goroda» [Official site of the Institute for Urban Economics Foundation]. Access mode: https://urbaneconomics. ru/en/node/21501 (Accessed 12/11/2021). (In Russ.)

7. Zubarevich N. Sotsial'naya differentsiatsiya regionov $i$ gorodov [Social differentiation of regions and cities]. In: PRO ET CONTRA, 2012, Vol. 16, no. 4-5, pp. 135-152. Access mode: https:// elibrary.ru/item.asp?id=25653327 (Accessed 01.12.2021). (In Russ., abstr.in Engl.)

8. Mazur L.R. Politikalikvidatsii neperspektivnykh dereven' $v$ 1960-1970-e gg.:istoki, etapy, realizatsiya,rezul'taty (na materialakh Urala) [The policy ofliquidating unpromising villages in the 1960s - 1970s: origins, stages, implementation, results (based on materials from the Urals). In: Rossiya $v$ XXv.: istoriya i istoriografiya : Sbornik nauchnykh statei [Russia in the XX century: history and historiography: Collection of scientific articles]. Access mode: https://elar.urfu.ru/ bitstream/10995/54585/1/5-7996-0150-5_2002_08.pdf(Accessed 11/25/2021) (In Russ.)

9. Shvetsov A.N. Polyarizatsiya urbanisticheskogo prostranstva: osobennosti rossiiskogo protsessa v kontekste mirovykh tendentsii [Polarization of urban space: features of the Russian process in the context of world trendsurs]. In: Regionalistika [Regional Studies], 2017, Vol. 4, no. 5, pp. 20-34. Access mode: https://elibrary.ru/ item.asp?id=30506831 (data brashcheniya11/16/2021). ). (In Russ., abstr.in Engl.)

10. Dmitriev M. Ekonomicheskaya gravitatsiya. Tsentrostremitel'nye i tsentrobezhnye sily aglomeratsii [Economic gravity. Centripetal and centrifugal forces of agglomeration]. In: Bol'she, chem gorod. Granitsy, masshtab i gravitatsiya gorodskikh aglomeratsii : Sbornik statei k Moskovskomu urbanisticheskomu forumu [More than a city. Borders, scale and gravity of urban agglomerations: Collection of articles for the Moscow Urban Forum]. Moscow, MUF Publ., 2021, pp. 28-43. Access mode: https://vk.com/ doc130708286_588149279?hash=5eb13f472be40214bc (Accessed 12/12/2021). (In Russ.)

11. Gertsberg L.Ya. Klasterizatsiya ekonomiki i rasselenie naseleniya : Monografiya [Economy clustering and population resettlement: Monograph]. Moscow, Novaya real'nost' Publ., 2021, 180 p. (In Russ.)

12. «Na Dal'nem Vostoke sobirayutsya sozdat' pervyi gorodmillionnik» - iz interv'yu s ministrom po razvitiyu Dal'nego Vostoka i Arktiki S.Chekunkova ["They are going to create the first millionplus city in the Far East" - from an interview with the Minister for the Development of the Far East and the Arctic S. Chekunkov]. REGNUM. Access mode: https://regnum.ru/news/3357420.html (Accessed 12/06/2021). (In Russ.)

13. Bokov A.V. Aglomeratsii: mnimoe i real'noe [Agglomerations: imaginary and real]. In: "Stroitel'nyi Ekspert». Portal dlya spetsialistov arkhitekturno-stroitel'noi otrasli ["Construction Expert". Portal for specialists in the architectural and construction industry]. Access mode: https://ardexpert.ru/article/16422 (Accessed 12/06/2021) (In Russ.)

14. Akhtyrko A. Inflyatsiya stala dvuznachnoi, kredity ogranichat. 0 chem rasskazali v TsB. Nabiullina: prodovol'stvennaya inflyatsiya dostigla dvuznachnykh znachenii [Inflation has become double-digit,loans will belimited. What was told in the Central Bank. Nabiullina: food inflation has reached doubledigit values]. GAZETA.RU. Access mode: https://www.gazeta.ru/ business/2021/11/18/14218081.shtml (Accessed 12/10/2021). (In Russ.)

15. Bouchet, M. Global Metro Monitor 2018 / Max Bouchet, Sifan Liu, Joseph Parilla, Nader Kabbani. - Brookings Institution, June 2018. (In Engl.)

16. Dikov, Ya.A. Tendentsii razvitiya gorodskikh aglomeratsii [Trends in the development of urban agglomerations]. In: Ekonomika i biznes: teoriya i praktika [Trends in the development of urban agglomerations], 2017, no. 7, pp. 24-28. (In Russ., abstr. in Engl.)

17. Na meste zavoda v Tushine poyavitsya zhiloi kvartal na 500 $000 \mathrm{kv} . \mathrm{m}$ [ $\mathrm{n}$ the site of the plant in Tushino, a residential area of 500,000 square meters will appear]. Vedomosti. Access mode: https://www.vedomosti.ru/realty/articles/2020/09/08/839089zavoda-tushine ( $\mathrm{n}$ the site of the plant in Tushino, a residential area of 500,000 square meters will appear. 12/06/2021). (In Russ.)

18. Minstroi sokhranyaet prognoz po vvodu $85,6 \mathrm{mln}$ kv.m zhil'ya [Elektronnyi resurs] // Interfaks-Nedvizhimost'. - Access mode: https://realty.interfax.ru/ru/news/articles/129195/ (Accessed 10.12.2021). (In Russ.) 